University of Nebraska - Lincoln

DigitalCommons@University of Nebraska - Lincoln

1965

\title{
Eimeria auratin. sp. (Protozoa:Eimeriidae) from Goldfish (Carassius auratus) in North America
}

Glenn L. Hoffman

Bureau of Sport Fisheries and Wildlife

Follow this and additional works at: https://digitalcommons.unl.edu/usfwspubs

Part of the Aquaculture and Fisheries Commons

Hoffman, Glenn L., "Eimeria aurati n. sp. (Protozoa:Eimeriidae) from Goldfish (Carassius auratus) in North America" (1965). US Fish \& Wildlife Publications. 138.

https://digitalcommons.unl.edu/usfwspubs/138

This Article is brought to you for free and open access by the US Fish \& Wildlife Service at DigitalCommons@University of Nebraska - Lincoln. It has been accepted for inclusion in US Fish \& Wildlife Publications by an authorized administrator of DigitalCommons@University of Nebraska - Lincoln. 
This article is a U.S. government work, and is not subject to copyright in the United States.

\section{Eimeria aurati n. sp. (Protozoa:Eimeriidae) from Goldfish (Carassius auratus) in North America

\author{
GLENN L. HOFFMAN
} \\ Bureau of Sport Fisheries and Wildlife, Eastern Fish Disease Laboratory, Kearneysville, West Virginia}

SYNOPSIS. Eimeria aurati n. sp. is described from the intestine of the goldfish, Carassius auratus, from Pennsylvania, U.S.A. Oocysts were very numerous in long, whitish, opaque

IN March, 1962 this laboratory received some gold1 fish for disease diagnosis from Mr. Richard Rice, Mercersburg, Pennsylvania. Seven of 29 fish examined were infected with Eimeria. These fish had long, whitish, opaque fecal casts hanging from the anus. The casts were composed almost entirely of oocysts. When shed, they sank to the bottom and looked somewhat like "spent" tapeworms (Figs. 1, 2). The infected fish were very lethargic and their intestines were swollen with contained fluid. Although I believe that the Eimeria is pathogenic, a heavy infection of other parasites made this difficult to determine. These fish had apparently accumulated a heavy load of fecal casts. They were 16 to 24 by 14 to $17 \mu$ (mean, 20.1 by 16.3) and were non-sporulated when passed but sporulated 2 to 5 days later.

parasites during the winter; Gyrodactylus, Trichodina, Chilodonella, Glossatella, Ichthyophthirius and Urophagus were present. Some also had bacterial infections of Aeromonas liquefaciens.

\section{Eimeria aurati n. sp.}

Description. The developing oocysts of Eimeria were abundant in the intestinal mucosa, and round oocysts were present in the lumen of the anterior intestine; seven such non-sporulated oocysts were 12$14 \mu$ (mean, $13.6 \mu$ ) in diameter (Fig. 5). The sporont extended to the thin wall, which was about $0.25 \mu$ thick. 

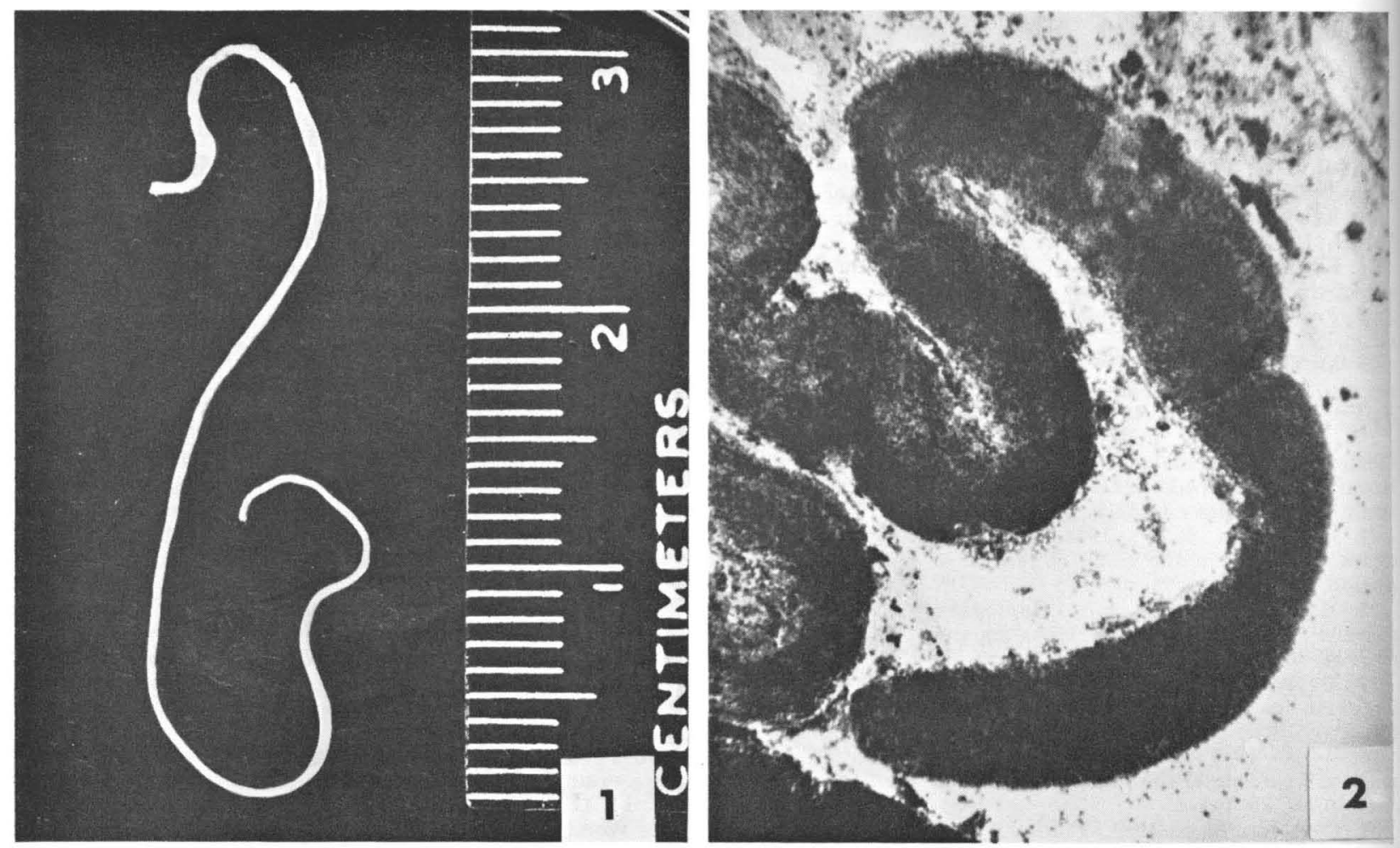

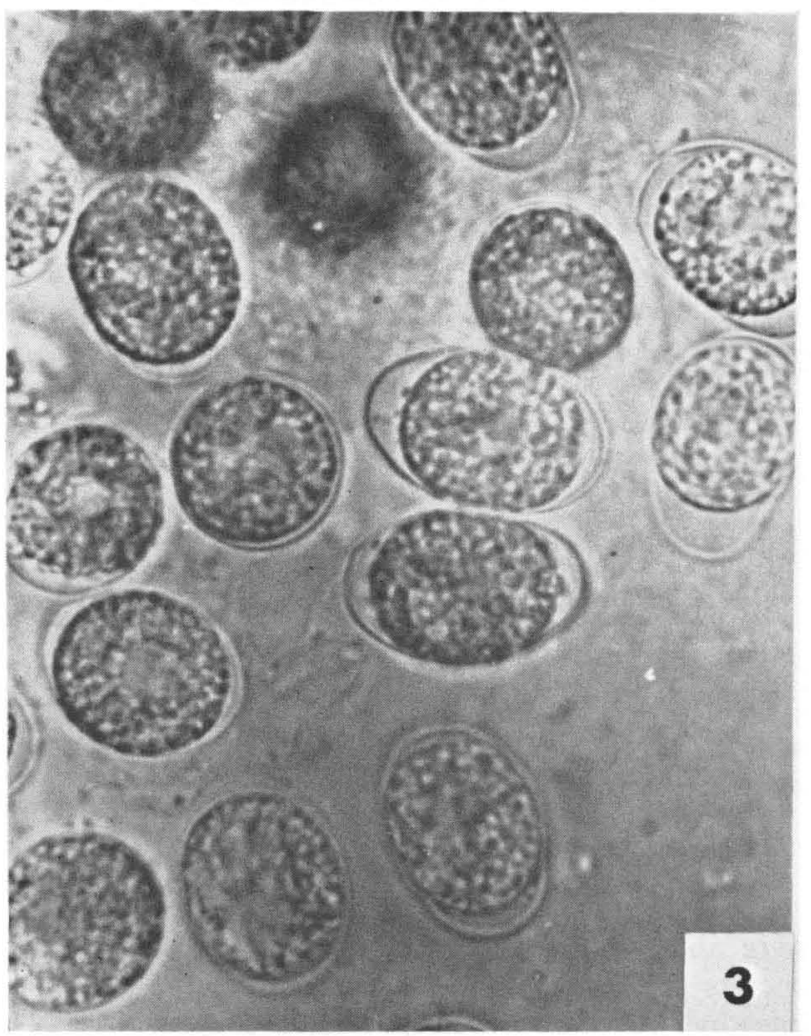

Fig. 1. Fecal cast shed by goldfish infected with Eimeria aurati n. sp. Fig. 2. Fecal cast, $24 \times$. Fig. 3. Freshly voided

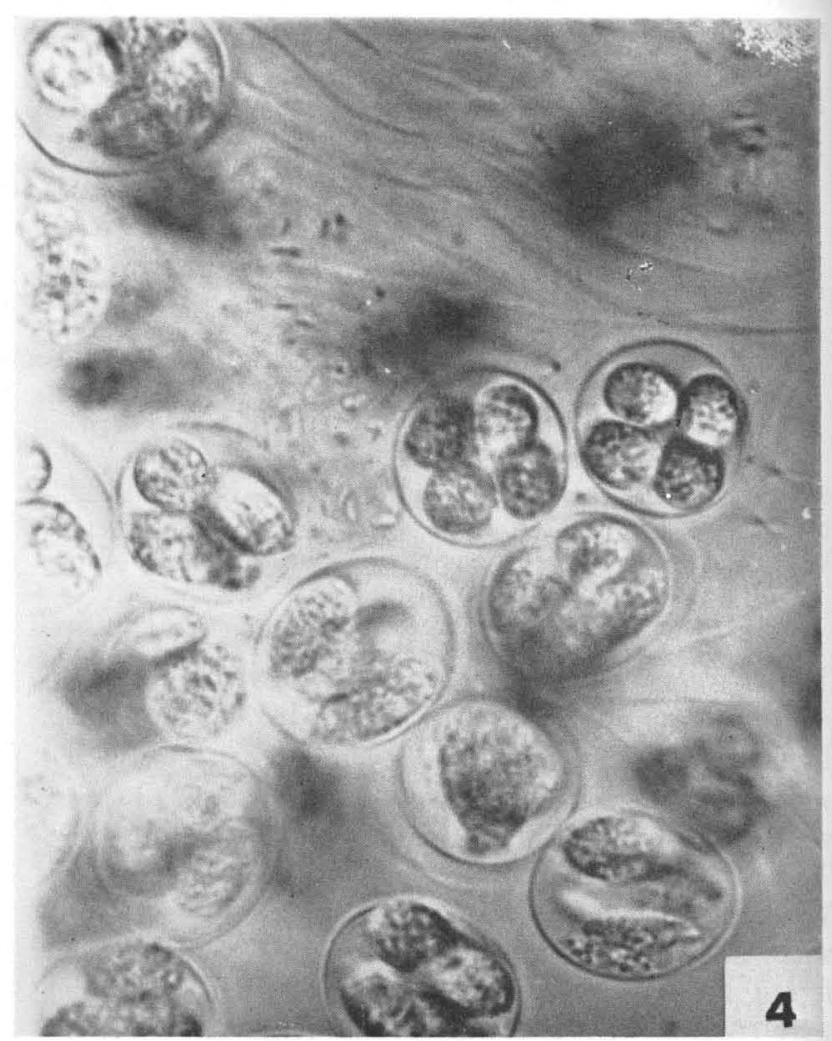

oocysts, non-sporulated, $640 \times$. Fig. 4. Oocysts containing sporocysts, sporozoites not yet developed, $640 \times$. 

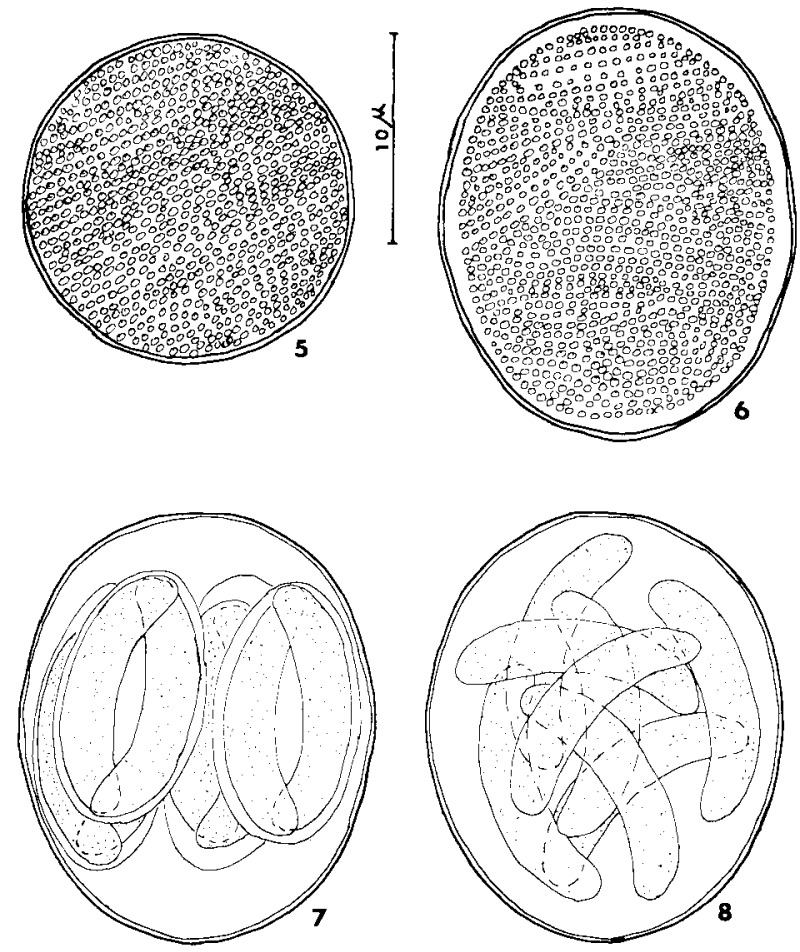

Figs. 5-8. Eimeria aurati n. sp. Free-hand sketches drawn to same scale.

Fig. 5. Round oocyst from intestinal contents, sporont not condensed. Fig. 6. Oval oocyst from recently shed fecal cast, sporont not condensed. Fig. 7. Mature oocyst containing fully formed sporocysts and sporozoites. Fig. 8. Old oocyst containing free sporozoites.

Most oocysts in freshly shed fecal casts were ellipsoidal, but they were still not sporulated (Figs. 3, 5, 6); they were 16 to 24 by 14 to $17 \mu$ (mean, 20.1 by 16.3). Oocyst polar granule, oocyst residuum and micropyle were absent. There were also a few round ocysts in the casts.

Fecal casts were collected and stored in vials of water. Sporulation took place in 2 to 5 days. Four ellipsoidal sporocysts developed in each oocyst; these were 11 to 13 by 6.5 to $8 \mu$ (Figs. 4, 7). The sporozoites were sausage-shaped and lay lengthwise in the sporocysts, nearly filling them. The sporozoites were 10 to 13 by 2 to $2.5 \mu$ (Figs. 7,8 ). There was no sporocyst residuum or Stieda body.

Remarks. Two species of Eimeria, E. carassii and E. nicollei were described briefly from goldfish in Belorussia (Russia) by Yakimoff and Gousseff (4). E. carassii had round oocysts measuring 19.5 to $24.4 \mu$; E. nicollei had oval oocysts measuring 21.9 to 31.7 by 13.4 to $19.5 \mu$.
The coccidian oocysts in the present study differ from those of $E$. carassii in shape and size, and from those of $E$. nicolle $i$ in size and in lacking a sporocyst residuum. In addition, they differ from both of these species in lacking clear globules in their sporozoites. The descriptions of $E$. carassii and $E$. nicolle $i$ are too incomplete to determine whether there are other differences.

Two species of Eimeria exist in the carp (Cyprinus carpio) in Europe, but have never been recorded from North America. E. carpelli Léger and Stankovitch(2) develops in the intestinal mucosa; its oocysts are round and only 8.5 to $14 \mu$ in diameter, and its sporocysts are 7 to $8.5 \mu$ long. The oocysts of E. carpelli are voided with sporozoites completely formed(5), whereas those of the present species are not sporulated when passed. E. wierzejskii Hofer, 1904, E. cyprini Plehn, 1924 and E. cyprinorum Stankovitch, 1921 are considered synonyms of $E$. carpelli according to Shulman and Shtein(1).

The second species, E. subepithelialis Moroff and Fiebiger (3) has oval oocysts 14.5 to $17 \mu$ in diameter, and sporocysts 10 to $12.5 \mu$ long. It produces coccidiosis with pea-sized subepithelial nodules in the carp intestine, whereas the present coccidia were found in the mucosa only.

The differences between the Eimeria described in the present paper and those previously described from goldfish and carp, justify the establishment of a new species for the present form. I am therefore naming it Eimeria aurati n. sp.

I thank Dr. Norman D. Levine, University of Illinois, for critically reviewing the manuscript.

\section{REFERENCES}

1. Shulman, S. S. \& Shtein, G. A. 1962. Protozoa. In Bychowsky, B. E. (editor) 1962. Identification of the parasites of freshwater fish of the U.S.S.R. Academy Science, S.S.S.R., Moscow-Leningrad, $776 \mathrm{pp}$. In Russian (translation in progress, Office of Technical Service, U. S. Dept. of Commerce).

2. Léger, L. \& Stankovitch, S. 1921. Sur le Coccidiose des alevins de la carpe. Compt. rend. 173, 742-4.

3. Moroff, T. \& Fiebiger, J. 1905. Ueber Eimeria subepithelialis n. sp. Arch. Protistenk. 6, 166-74.

4. Yakimoff, W. L. \& Gousseff, S. F. 1935. Kokzidien bei Fischen (Carassius carassius). Z. Infektionskrankh. Houstiere 48, 149-50.

5. Zaika, V. E. \& Kheisin, E. M. 1959 Carp coccidiosis on the Valdai Fish Farm. In Bauer, O. N. (1959) Parasites of freshwater fish and the biological basis for their control. Bull. State Sci. Res. Inst. Lake and River Fish. 49, 227-30. (English translation, Office of Technical Service, U. S. Dept. Commerce, No. 61-31056.) 